\title{
Mapping the Traumatized Subject in Chinese American Literature
}

\section{Faten Houioui}

The literature that represents extreme physical and psychic violence hinges on the recorded experiences of the survivor. Such literature is read and interpreted in light of trauma theory. However, trauma studies are generally restricted either to Holocaust Studies or African American or Native American Literature. The holocaust 1 is being represented, theorized and even canonized in relation to trauma studies. Consequently the focus on one group's traumatization minimizes the sufferings of other groups such as the Chinese immigrants to the United States of America before the Communist takeover in 1949.

Asian American literature was coined in the late 1960s.It is defined as "works by people of Asian descent who were either born in or who have migrated to north America" (Cheung: 1). It encompasses Chinese, Japanese, Korean, Vietnamese and Filipino American literature. In the writings of Asian Americans "the immigrant experience looms large" with issues related to "marginality and life on the border (...) biculturalism and language, and decisions about identity" (Huntley 19). Thus their writings are a product of specific historical contexts. The largest Asian immigrant group was the Chinese. Hence the traumatized Chinese experiences range from atrocities witnessed in wars, revolutions to the communist takeover. Furthermore they are culture bound in terms of the causes of trauma as well as the reactions. My paper willfocus on Amy Tan second novel The Kitchen god's Wife. I will analyse the novel focusing on the main female traumatized subject Winnie Wen. The text shall be read in light of trauma theory as it is a trauma-ladden novel. Amy Tan challenges the westernized notion of Post Traumatic Stress Disorder by showing that female characters experience a different kind of effects and react courageously: they resist, outlive trauma and testify.

Winnie experiencedhorrible atrocities which remainedher unspeakable secrets for over forty years. She is first traumatized at the age of six by the enigmatic disappearance of her mother, then she lives with her uncle for over twelve years as "left overs for [her] mother's disgrace" (134 TKGW $\left.{ }^{1}\right)$. Then she marries Wen Fu, an unscrupulous military husband, who assaults her sexually andmorally. She endures perilous traumatic events with him: he kills two of their daughters, Yikuand Mochu, while her son Danru dies during the Sino Japanese war. Winnie's first marriage,contends Huntley, "introduces her to pain in all of its manifestations-physical, emotional,spiritual, and psychological." (87) As a trauma survivor, she resists traumatization throughaborting three babies in the first months of 1942; thus she adopts survival strategies and doesn't succumb to moral despair.She reconstructs a traumatic memory through the process of giving her testimony to her American-born daughter. Her trauma stories, which are not totally repressed, nonetheless initially remain unvoiced, obscuring both her past and her Chinese history in her present American life. She will externalize her trauma talespreserved in her traumatized memories - with the help of her Chinese friend Helen (Former Hulan). The latter helps Winnie to decode the inner workings of her psyche, and retrieve and construct her trauma stories. She (Helen) lies to the American born daughter that she has a brain tumor and she "want[s] to correct everything before it's too late, no more secrets, no more lying."(TKGW 90)

This lie is a twist used by the narrator to divulge that the daughter also has a secret traumatic story, hidden from her mother, that aunt Helen "can no longer keep." (36) The encounter between Helen and Pearl on one side and Helen and Winnie on the other signals a new beginning and transformation for the two survivors. Winnie has been immersed in physical and moral trauma for over forty years and "had worked so hard to forget" (91) her Chinese past. However, when confronted with Helen's decision to unravel all her secrets she (Winnie) breaks the silence that prevents her from confronting my past, my marriage to Wen Fu, everything" (90). Hence Winnie decides to reveal the destructive traumas she underwent and acknowledges that: "I will say I have to tell you something can't wait any longer. And then I will start to tell you, not what happened, but why it happened, how it could not be any other way" (100).

Consequently this statement shows that the trauma survivor may become reconciled with destructive traumatic events - even though it is prolonged repeated trauma in the case of Winnie - and confront the traumas considering them as events in her life. Moreover, in the case of Winnie, even though before testifying through the mere decision of voicing the trauma she becomes reconciled with the destructive traumas inflicted on her body and psychology. She considers the traumas-which after forty years she decides to testify to her

${ }^{1}$ This is an abbreviation of The Kitchen God's Wife, I shall use henceforth.

DOI: 10.9790/0837-220501119126 www.iosrjournals.org


daughter - necessary experiences she lived in a given context .Interestingly, Winnie's traumatic experiences only settle into her understanding after forty years and she retrieves them in their immediacy as if they had just occurred. Although Winnie was subject to chronic and prolonged traumas, she transcends them and survives. She was long and repetitively abused by the exploitative practices of her husband. Her traumas range from random beatings, brutal rape and other humiliating practices, such as insults, that she divulges to her daughter.

Albeit trauma theorist Cathy Caruth considers that the traumatized "utter hallucinations and dreams" that are "absolutely literal, unassimilable to associative chains of meaning" (4) and that "the images of traumatic reenactment remain absolutely accurate and precise they are largely inaccessible to conscious recall and control" (151), ShoshanaFelman maintains that "self-knowledge [...] does not exist, it can only happen through the testimony, it cannot be separated from it. It can only unfold itself in the process of testifying" (53 Italics in the original). Being a survivor of chronic and repeated personal trauma who experienced, among other things, war atrocities, Winnie has full accessto her trauma stories: she retrieves them in a different context both geographically andlinguistically; she reconstructs the trauma she lived back in China in The United States in English.

Through giving her testimony, Winnie rescues her story from undeserved obscurity. She both recovers and recognizes the atrocities she was subject to. She confesses to her daughter "[c] an you imagine how innocent I was, how strong my innocence? (...) I was still dreaming of celebrations, I would hold, of happiness yet to come." (186) Then she regrets "I was innocent (...) and I lost my innocence, and always regretted what I lost. And because I lost so much, I remember so much" (202). Her identity undergoes modifications imposed by her husband's bestial behavior. He perpetuates her expectations, her faith and her physical and moral integrity all of which determine her identity, through the multiple atrocities he imposes on her. When Winnie refers to Wen Fu, her first husband, she describes him as a "terrible son-in-law-no feelings, no morals, no shame" (410) and "that bad man" (99). He inflicts physical and moral torture upon her. One example of his multiple random beatings and insults is when he tells her "I am a sick man, you are a healthy woman! I am a hero, you are a whore! Your two eyes see other men! (...)You are wrong. Kneel down. Bow your head and beg me to forgive you kneel down! He slammed the stick on the table" (318) and "he reached over and slapped me, gave me a real slap in front of all those people. I grasped I did not feel any pain. I thought the stinging was just my embarrassment" (319).

Accordingly Wen Fu, the authoritative, violent, drunken perpetrator, abuses his wife first morally, then physically and finally sexually. Through his humiliating insults and practices: "kneel down" "bow your head," he overcomes her will and transforms her into a dependent subject terrorized by physical pain and constant beatings. Therefore, the survivor's moral and physical insecurity breaks her psychological integrity and shatters her defense mechanisms. Winnie's subordinate condition to her husband is further maintained by his frequent brutal rapes after forcing her to write her own divorce paper. Accordingly her psychological traumas are aggravated by Wen Fu's repetitive assaults, exposing her to prolonged traumas. The latter, posits Herman "occurs only in circumstances of captivity" (74). In this condition the victim is a prisoner (wife) under the control of the perpetrator (husband). Herman labels this condition "domestic captivity" in which women are "rendered captive by economic, social, psychological, and legal subordination, as well as by physical force" (74). To begin with, Wen Fu torments Winnie and makes her write and sign her own divorce paper with a gun at her head. The scene goes like this

"Whore! Fox-devil! Traitor! Now I am divorcing you write that down (...) when I looked up I saw he was pointing a gun to my head, smiling crazily. "It's no use! Our marriage is finished" he said "if you don't write this I will kill you!” (...) You see you are divorced (...) worth nothing. You have no husband. You have no home. You have no son (...) Beg me to tear up that divorce paper" he said. He moved the gun closer to my head. His mouth was ugly and wild, like a crazy person's, but his eyes were clear" "Do it" he shouted. "Get down! Beg me (...) he wanted to see me suffer" (392-3)

What is at stake in this trauma testimony is that the woman survivor-after forty years-gains access to her trauma experiences, analyses the moral torture she endured and fully describes the perpetrators facial expressions "crazily (...) ugly and wide". She perceived his deliberate intentions to injure her and reduce her to nothingness through repeating "nothing (..) no (..) no (...) no (...)". The assailant- Wen Fu- "terrorizes, dominates and humiliates his victim to render her helpless" postulates Herman; "consequently rape intentionally produces psychological trauma" (58).

Therefore Winnie's psychological impairment is the consequence of her husbandbeing "[a]uthoritarian, secretive, sometimes grandiose, and even, paranoid," concurs Herman (75). Furthermore, the survivor testifies that [t]hat night, with a gun to my head, he raped me, telling me I had lost the privileges of a wife and now had only the duties of a whore. He made me do one terrible thing after another. He made me murmur thanks to him. He made me beg for more of his punishment. I did all these things until I was senseless, laughing and crying, all feelings in my body gone (394 Italics added). Then "I did not say anything about the rape, although any smart person could have seen this: my hair, my torn dress, Wen Fu fastening his pants" (503) 
Winnie kept silent about the rape she underwent in her marriage because of fear and shame. Consequently she suffers from a pattern of symptoms identified as "rape trauma syndrome," recognized in the American Journal of Psychiatry in 1974. The pattern of psychological reactions can be summarized by fear of mutilation and death during the assault, and after it survivors complain of insomnia, nausea, startle responses and nightmares as well as dissociative or numbing symptoms" (Herman 31). Indeed the rape survivor admits that she felt senseless without any feelings; so she is distraught experiencing life threatening traumas (rape and battery). In her Women and Madness, Phyllis Chesler notes that rape is "about humiliating another human being through forced or coerced sex and sexual shame. The intended effect of rape is always the same: to break the spirit of rape victim, to drive her (or him) out of her body and quite often out of her mind, to render her incapable of resistance." (35) Winnie suffers under domestic captivity "humiliating assaults that have lifelong effects".

What is stunning in her trauma narrative is that the rapist's bestial behavior is increased by "violence, threat of death, serious harm, threats against others (abuser threatens to kill children, parents (...) as well as by inconsistent and unpredictable outbursts of violence"(Herman 77). Wen Fu-the unfaithful rapist husband-is responsible for many crimes against other Chinese women. He raped their fourteen-year old servant, who dies trying to abort. Then his wife confesses that "he was sleeping also with many different kinds of women: native girls, prostitutes even a school teacher" (125). His cruelty and violence are innate and he misbehaves even with the nurses; his wife reports that "he threw his food at the nurses and called them whores of the devil (...) he threw a bed pan at the doctor who saved his life" (314). This Chinese military husband is portrayed as obsessed with physical, moral and sexual violence. He even beats his baby daughter

He slapped her-Kwah! - hit her hard on the face, so hard half of her face turned red."Quiet" he shouted. Her eyes were pinched closed. Her mouth was open, but nosounds came out. She could not breathe. So much pain! I can still see that look on her face, hurting worse than any slap to my own [...] Wen Fu hit her again. Kwah-again and again. After this she became a strange baby (331-2)

Witnessing her babies' deaths, Winnie co-owns an additional psychological trauma.Eventually Winnie's testimonies reveal a previously unexposed picture of her sufferings, and since the listener is her daughter-who is already silently invisibly traumatized - she comprehends her mother's trauma experiences and shares her feelings, a fact that helps her heal her (the mother's) wounds. In the process of testifying, the survivor goes through a moment of recognition. She recognizes her traumatized identity/self during her first marriage in China and gains access to the violent domestic and sexual abuses she goes through "[w]hat is important is the situation of discovery of knowledge - its evolution, and its very happening" posits Dori Laub in his article "Breaking Witness," adding that "knowledge in the testimony is, in other words, not simply a factual given that is reproduced and replicated by the testifier, but a genuine advent, an event in its own right." (62).

Therefore, Winnie's self-discovery occurs when she testifies concerning her traumas. She subverts the irretrievability of traumatic memories and her testimony evolves gradually from the mostintricate to the simplest eventWinnie's testimony is a discursive space where she works out the painful impact of her traumas. It grows out of her repressed memories; although " $\mathrm{t}] \mathrm{he}$ act of telling might itselfbecome severely traumatizing, if the price of speaking is re-living, not relief, but further retraumatization." (67 Laub italics in the original) However, Winnie's listener alleviates the sufferings of reexperiencing the event itself through truly hearing her mother survivor. Further, in reconstructing the traumatic memories, the survivor regains the fragmented painful events. In this line, Jonathan Shay, considers that

"[s]evere trauma explodes the cohesion of consciousness. When a survivor creates a fully realized narrative that brings together the shattered knowledge of what happened, the emotions that were aroused by the meanings of the events and the bodily sensations that the physical events created, the survivor pieces back together the fragmentation of consciousness that trauma has caused" Achilles in Vietnam188].

Consequently, for Shay, traumatic events inflict disorder on the victim's personality (for Winnie suffers from both Post Traumatic Stress Disorders and Rape Trauma Syndrome) and recovery occurs in - as much as the survivor is able to "create" a narrative without specifying oral or written - the ability to piece back the fragmented knowledge of the experience.

Winnie's personal traumas are not specific to her; they represent many Chinesewomen's traumas during the Sino-Japanese $\mathrm{War}^{2}$. Hence there is an intersection between the private traumas/history and the public ones. Since her husband is a Chinese military pilot she experiences the war and has a life of "Toanan", which means "a fear that chases you, a sickness, exactly like a hot fever in your brain" (260), thus "your only thoughts are "Escape! Escape! — nothing else, day and night" (260). Consequently many pilots and officers keep on escaping with their wives from one place to another by boats and lorries till they reach Kumming, which lies at

\footnotetext{
${ }^{2}$ This war is fictionalized in The kitchen God's Wife. One of the characters experienced it and was excessively traumatized by the bombings, rapings...such war contributed to the identity construction of the Chinese-

American subject : male and female
} 
the end of China and could be considered as a safe place during the war. In Winnie's testimony related to her daughter, she makes space for revision and allows the resurfacing of the Sino-Japanese War that is concealed in the Western historical accounts of World War Two. Winnie is both a witness and a surviving victim of the war. Her wartime memories construct not only a description of the war events ranging from bombing, killing and raping to war casualties, but also a proof that rescues the untold, unrepresented personal/collective history-i.e. Winnie's history and by extension Nanking's - from oblivion. In The Kitchen God's Wife, Amy Tan does not merely offer an alternative history for the Chinese and the Chinese Americans, she rewrites their history. She historicizes her narrative and fictionalizes the historical narrative. Indeed in "The Historical Text as Literary Artifact" Hayden White contends that no set of recorded historical events can constitute a story though it offers the historian story elements. For this aim all the techniques necessary in the emplotment of the novel such as descriptive strategies, point of view, variation of tone, motif repetition,characterization and suppression, and subordination of certain events are indispensable (84). In fact, Amy Tan's The Kitchen God's Wife establishes a parallel between the fictional character's psychological traumas and the real Chinese women's trauma during the Sino-Japanese War.

The novelist fictionalizes the historical discourse by adding imaginative characters and events. Tan appeals to different sources of documentation and empirical research. She investigated the Japanese atrocities in China relying on the personal oral narratives of her mother. Trusting her mother's recollections of the war, she rebuilds the Sino-Japanese War in a historical/fictional discourse. Back in China, Tan's mother, Daisy Tan, was married and had three daughters whom she left when she immigrated to the USA in 1949. Her husband was a pilot "dismissed from the air force for bad morals" (The Opposite of Fate 208). Her mother "began to tell [her] details of their life in China - of bombs falling, of running to escape, of pilot friends who showed up for dinner one week and were dead the next" (ibid). Therefore the mother's personal accounts construct and rewrite history for the Chinese Americans. And insofar as the narrativized historical discourse represents events of oppression, massacres and torture written by the traumatized, oppressed witnesses, one can say that Amy Tan suggests the possibility of an alternative historiography based on testimonies and recollections of memories rather than official documents. Hence, the traumatized subject Winnie Wen stands for the novelist's mother. The former postulates that"when the Japanese army invaded the capital city, they [r]aped old women, married women, and little girls, taking turns with them, over and over again. Sliced them open with a sword when they were all used up. Cut off their fingers to take their rings. Shot all the little sons, no more generations. Raped ten thousand, chopped down twenty or thirty thousand, a number that is no longer a member no longer people. (295) However, "the real number of people who died was much, much worse" (Ibid). In line with this, historian Chang reveals that [a]n estimated 20,000-80,000 Chinese women were raped. Many soldiers went beyond rape to disembowel women, slice off their breasts, nail them alive to walls.

"Fathers were forced to rape their daughters, and sons their mothers, as other family members watched. Not only did live burials, castration, the carving of organs and the roasting of people become routine, but more diabolical tortures were practiced, such as hanging people by their tongues on iron hooks or burying people to their waists and watching them get torn apart by German shepherds"(6).

For Chang, the Sino-Japanese War is the other Holocaust, and denying this historical event is a second Holocaust, so writing about it is stopping the Holocaust/rape. In the above mentioned book Chang compares the Japanese in Nanking to their Nazi counterparts in Germany. Therefore writing about the rape of Nanking constitutes a kind of closure to the second Holocaust. In 1937, Nanking - the capital city of nationalist Chinafell to the Japanese, marking the start of World War II in Asia; it would not be evacuated before 1945 with the Japanese defeat. The invasion is labeled the Rape of Nanking or Nanking Holocaust, first for "[ $t$ ]he Japanese raped Nanking women from all classes: farm wives, students, teachers, white-collar and blue-collar workers, wives of YMCA employees, university professors, even Buddhist nuns some of whom were gang-raped to death" (90). Second, the war was an Asian Holocaust taking place concomitantly with Europe's Holocaust. Indeed the torture inflicted by the Japanese upon the Chinese resembles what Jews suffered in Europe.

The Japanese war atrocities were live burials, mutilation, deathby fire, death by ice, rape and mass execution. In The Rape of Nanking: the Forgotten Holocaust of World War II, Chang refers to a wide range of different material such as diaries and testimonies of Japanese soldiers, Chinese survivors as well as Western war veterans (businessmen, journalists, missionaries) who provide detailed eye-witness accounts of the massacre. The latter were traumatized by the atrocities committed and retrieved their memories in diaries that the historian unearthed.

Ultimately Chang contends that "[t]he Rape of Nanking had been a deep, festering wound in the city's psyche, a wound that hid years of repressed fear and hatred" (170 italics added).The Rape of Nanking as represented by historians, whether Chinese or Japanese, and narrativized by traumatized women survivors is a holocaust, and not only a historical trauma but also a "founding trauma" which is "typical of myths of origin and may perhaps be located in the more or less mythology history of every people." (81) Consequently this historical trauma has played a decisive role in shaping Nanking's history, psyche and identity construction. 
The traumatic crimes against Chinese women by Japanese soldiers parallel the crimes of sexual violence against Chinese women by the perpetrator Wen Fu. And although Winnie Wen asserts that "[w]hat happened in Nanking [she] couldn't claim... as [her] tragedy, [she] was not affected. [She] was not killed." (295) She testifies that after a Japanese bombing raid on Kumming's market"[she] saw lot of people dead, injured, terrible sights, shoes without feet, feet without legs" (347). Moreover "[t]he planes kept coming, may be three times a week, always in themorning (...) Bomb Kumming in the morning, Chunking in the afternoon. And for us, thebombing became part of our lives." (371)

In Amy Tan: Contemporary World Writers, Bella Adams considers that the events of the war and the historical trauma Winnie experiences are so shocking that she becomes unable to conceptualize shock or fear (82). Her ideas about space, time and reality undergo crisis (ibid): Winnie testifies that

"I did not know whether I had fallen or whether the explosion had pushed me down, whether one second had passed, or one day...I thought maybe I was dreaming, because people were walking slowly, as if they were still dreaming too. Or perhaps we were dead and now waiting to go to the next world....and lying on the roof tops and in the road were all the things that...I did not want to recognize" (295-6).

Moreover, Winnie refers to the war "as if [it] were an epidemic, spreading around sickness" (203).

This analogy, asserts Adams, is practically relevant to the Japanese military in its assault on targets in excess of the conventions governing warfare (82). Consequently and due to the war atrocities perpetrated by the Japanese, Winnie deems "[t]he war was like a bad illness, and when it was over, it did not mean everybody suddenly became healthy again" (359), an idea maintained by Adams when postulating that "The Kitchen's God Wife" in and of itself also articulate[s] the impossibility of a post-war return to "health" when such excessive violence makes impossible "smart thoughts," if not categorization per se" (82). In connection with The Rape of Nanking, Amy Tan revisits an important historical event in Chinese history, subverting the traditional assumptions about history as objective and valid. The Kitchen's God Wife "puts into question the West's representation of the 1930s and 1940s." (79 Adams)

American history books give the date of 1939 as the beginning of World War Two in China; Winnie's historical traumas implicate the West in numerous historical catastrophes adds Adams (79). She cites the example of "Britain's closure of the Burma Road, which prevented war supplies reaching the Chinese, and, America's 'big business with the Japanese selling them gasoline and metal for air planes' - the same ones that were dropping bombs all over China (359/360)." Just as Winnie's psychological traumas are kept secret, the Chinese women's torture, rape and murder are kept invisible, yet leaving a permanent imprint in Nanking's history and the Chinese women's psychic construction. Therefore, representing historical and psychological traumas in writing and through testifying is one way to come to terms with the past and by extension history.

In Post Traumatic Culture, Injury and Interpretation in the Nineties, Kirby Farrel considers that "[a]s an interpretation of the past, trauma is a kind of history. Like other histories, it attempts to square the present with its origin. The past can be personal or collective, recent or remote: an artifact of psychoanalysis or an act of witness (...)to account for misfortune or violation." (14) What I discern from Farrel's view is that if trauma is at the same time collective, personal, recent or remote history, so that history confronts the present by its roots, so Winnie's traumatic personal history is a personal space that encompasses and reflects the traumatized collective history that haunts the present and destroys it on the personal and collective level, in order to recognize and rebuild it. When narrating her trauma experiences, Winnie suggests that her war time experiences were not the worst part of her life; rather what aggravated Winnie's psychic trauma is " what happened next and then after that. The worst was never knowing when it would stop" (397). Since she was subject to prolonged trauma and her perpetrator, her husband, was a criminal, a rapist and a murderer, she is more appalled by her personal traumas than by the war atrocities she witnessed. And even after immigrating to the United States of America, she carries with her a "mind-blowing" experience that destroys a conventional mind-set and complex (or makes possible) a new worldview" (19 Farrel). Ultimately Winnie will only recover after giving her testimony. Winnie manages to survive her prolonged traumas and reengage in life while she was with her perpetrator husband and during the Sino-Japanese War. She resists atrocities and lives to relate her story/testimony. Indeed survivors are determined either to survive and tell their stories or let their stories outlive them .

In The Trauma Question, Roger Luckhurst points out that the traumatic past returns insistently and haunts the survivor. Thus recovery depends on relief, which cannot be achieved by simply forgetting traumas (96). He contends that "it is necessary to overcome a pathological relation to the traumatic past, to be relieved of its violent insistence, in order to recover a sense of self and the possibility of community, but this cannot be done by a simple forgetting"(ibid). This is to say that the survivor has to act out then work through his traumas. In post-traumatic acting out, the survivor is "haunted or oppressed by the past" argues Dominick LaCapra in Writing History, Writing Trauma "and performatively caught up in the compulsive repetition of traumatic scenes"; while "acting out, tenses implode, and it is as ifone were back there in the past reliving the traumatic scene."(21) He further asserts that"[a]ny duality (or double inscription) of time (past and present or future) is 
experientially collapsed or productive only of aporias and double binds. In this sense, the aporia and the double bind might be seen as marking a trauma that has not been worked through."(21)

Starting from this definition of acting out, I can argue that both LaCapra and Caruth agree about the haunting effect of trauma. Thus the Chinese American subject( male and female) is haunted by the traumatic experiences lived in pre-communist China. Indeed, the latter posits that "to be traumatized is precisely to be possessed by an image or event" (4/5 95) which occurs, evidently, in the aftermath of the traumatic experience. Consequently the traumatized relives the events compulsively, without remembrance of details.In addition, what determines "the compulsive repetition" is the consistent presence of the after effects of trauma, mainly if the traumatic event "has no beginning, no ending, no before, no during and no after." (69) Ultimately, since in acting out the traumatic experience, events are relived "acting out may well be a necessary condition of working through" the traumas (70). On account of this, one works through trauma provided that "one is able to distinguish between past and present and to recall in memory that something happened to one (or one's people) back then while realizing that one is living here and now with an opening to the future" (ibid 22). Thus LaCapra states major processes of working through: critical thought and practice whichinvolve the possibility of making distinctions or developing articulations and resistance(ibid). Consequently working through enables both survival and reengagement in life: LaCapra cites an example of a survivor in the process of working through his/her traumas; the traumatized gains critical distance from the event, distinguishes between past, present and future and comes to terms with the traumas. So s/he is able to say "yes, that happened to me back then. It was distressing, overwhelming, perhaps I can’t entirely disengage myself from it, but I am existing here and now, and this is different from back then." (144) LaCapra's fictional statement about the survivor is almost uttered by, Winnie Wen ; who acknowledges that "I will start to tell you (her daughter), not what happened, but why it happened, how it could not be any other way" (The Kitchen God's Wife100). In the case of Winnie, her decision to unravel the trauma symbolizes that she is reconciled with her destructive past.

While working through a traumatic experience the survivors engage in various behaviors to resist all types of chronic or prolonged traumas. The Chinese mother, her American daughter and their grandmother create productive strategies to cope with their traumas; hence the narratives of resistance map out their strategies of resistance which vary from using one's body (abortion and suicide) to writing and keeping silent. In so doing, the survivors recreate their experiences, recover their histories and heal themselves. The trauma survivor Winnie Wen engages in diverse behaviors to fight and resist her prolonged traumas. She refuses to submit and develops resisting techniques both direct/visible and indirect/veiled. Despite the fact that she "was abandoned by her mother, married a man prone to violence and mania, and further, endured the deaths of her first three children, her hated husband, and her beloved second husband, Jimmy Louie" (Cooperman95), Winnie manages to appropriate her traumatic state through multiple coping or survival strategies both physical and psychological. To cope with the distress of being repeatedly traumatized, the first action the survivor takes is twice escaping her marriage. Confessing that "I did not think I was ready to die, not yet" "I can find a way to escape" (361), she fights to create new possibilities and escape first during the war then after it. Moreover, this victim not only resists her husband's frequent assaults and rape but also his violent beating of his two babies as "she always cried, cried all night long, and would not stop until I told her more lies "Yiku, be good, and your life will be good too." (326) However when her daughter dies, the mother admits "[she] knew [she] didn't have to lie to her anymore." (338) Therefore Winnie's coping strategies make it clear that she has resilient characteristics, which enable her to survive her abysmal experiences with Wen Fu. She recounts that "[f]or the rest of the war, I lived a life without hope. But without hope, I no longer despaired. I no longer fought against my marriage. Yet I did not accept it either. That was my life, everything always in between-without hope, yet without despair, without resistance, but without acceptance." (399 Italics added) Concerning "I no longer fought against" and "without resistance" I need to clarify that the survivor relates this after the first abortive attempt to escape her marriage.

"Highly resilient people" contends Herman "are able to make use of any opportunity for purposeful action in concrete with others, while ordinary people are more easily paralyzed or isolated by terror. The capacity to preserve social connections and active coping strategies, even in the face of extremity, seems to protect people to some degree against the later development of post traumatic syndrome." (58) Herman's statement applies to all the traumatized characters inasmuch as their resistance is identity based. Through a wide range of "purposeful action(s)" and "active coping strategies," Winnie Wen protects herself and develops defense mechanisms to survive. She considers that "it is part of our nature to let go of brave thoughts at the last moment and cling to hope and life." (417-8) Hence her resistance is innate and natural, and is strengthened by the traumatic experiences she is subject to. Besides, the more severe her traumas are, the greater her resistance becomes, and she "dream[ed] the future would come, perhaps the next day, or the day after that. And when it did [she] could then reclaim [her] happy past-one that really existed" (345). When retrieving her traumatic memory up to the present, Winnie admits that she uses her body to protest against Wen Fu's rape. She decides 
to have an abortion for every pregnancy she has after her unsuccessful attempt to escape. Indeed she exclaims "how foolish I was! To think my body was my own, something to protect or lose for myself" (393).

However she "went to the doctor and the baby came out before it could be born. Two months later, the same thing.Two months later the same thing. We had no birth control, back then" (397).Winnie "killed lots of babies" (397) as "[t]hat bad man was using [her] body. Every night he used it, as if [she] were-what? A machine!" (208). Thus Wen Fu, the perpetrator, not only traumatizes her physically — through rape-but also psychologically by exploiting her body; he pushes her to abort and carry the moral guilt of this act.

Moreover, Winnie succeeds in preserving social connections despite the variouspainful experiences she lives during the war. First she builds a sense of self-esteem through her friendship with Hulan, her husband Jiago and Auntie Du, and integrates into this community. Then with attending parties she develops positive emotional responses. In fact she meets her beloved second husband Jimmy Louie - a Chinese American soldier at an American Dance on Christmas 1941 - and she will live with him in 1945 when she escapes from her abusive husband to Shanghai. Though she lives through multiple excruciatingly traumatizing experiences in China, Winnie proves to be a highly resilient character who adopts survival strategies to reengage in life. She summarizes that

"Wen Fu had gambled away almost all [her] dowry money: when there was no more money to steal from [her], he used [her] own body like a gambling chip, laughing and telling the men they could sleep with [her] if he lost!' [she] remembered the many nights he used [her] body after he had already been with another woman: 'he even brought a woman right to [their] bed and forced [her] to watch. Of course, [she] did not, but [she] could not shut [her] ears." (409).

Winnie undergoes her horrendous experiences and acquires strength from them. When describing her husband divorcing her as he points a gun to her head, she comments ironically "[h]e needed no such force" as she is "given a crazy kind of luck" so she "was writing fast" feeling [she] would soon be free" (393).

Mapping out Winnie's strategies of resistance, I would say her resistance is not sporadic, but is rather consistent. She is determined to resist and survive through restoring her connections with community, with her cousin Peanut, and her friends as well as her distant relatives, which is a fundamental stage in recovery in the aftermath of trauma. Being confined in her marriage, rendered helpless, subjected to humiliation and exploitation, she learns to fight and reconnect with others to reengage in life. Winnie's productive strategies to cope with her trauma strengthen her determination to survive. In her last scene with Wen Fu she mobilizes effective defense strategies, especially when she takes the gun from her husband and threatens him: she contends that "I pulled the trigger, thinking to hit the floor and scare him a little. But the gun exploded so fast it yanked my hand back, and a bullet flew past Wen Fu's head and landed in the wall behind him." (503)

Moreover there are instances where traumatized female subjects resort to suicide to end their sufferings; such as the case of the fourteen-year old servant. Suicide cases are also prominent in the text. Besides while psychiatrists and clinicians assess factors, prevalence and motives behind suicide, suicide for the traumatized female subjects has totally different characteristics than those defined in medicine, psychiatry and related disciplines. This disparity is induced by the fact that suicide is culture bound. Indeed within a Confucian, traditional context, suicide is associated with vengeful ghosts who appear at specific times in the lunar year bringing bad luck and calamities. With a strong belief in spirituality the family of the victim hires ghost catchers but they have to honor the family of the dead.

Mapping the traumatized subjectivity of Chinese American women is not a simple task if we probe the multiple trauma they suffer from, in terms of aftereffects and causes. Trauma is transmitted across generations both physically and morally. The subject is either predisposed to trauma or already suffers from unexplained trauma $^{3}$. Thus trauma is a crucial factor in the identity construction of the Chinese /American female subject. Under this experience and theory (of trauma) lies the cartography of subjectivity as delineated by Amy Tan: a history of inherited trauma from pre-communist China worsened by 'Americanized' daughters who refuse to be Chinese and who bear traces of their mothers' traumas.

However; the female Chinese subjects reconstruct the trauma story-which include - their resistance and testimonies. Furthermore, though Winnie was subject to both chronic and prolonged traumas, she transcends them and survives. Her personal traumas are not specific to her; they represent many Chinese women's traumas during the Sino-Japanese War. Hence there is an intersection between the private traumas/history and the public ones. In The Kitchen God's Wife, Amy Tan does not merely offer an alternative history for the Chinese and the Chinese Americans, she rewrites their history. Consequently retrieving traumatic experiences in this text acquires a different interpretation and identity construction-by extension-it encompasses the Second World War female victims. The latter are doubly traumatized, by the Japanese soldiers and the Chinese males (as represented in the character of Wen Fu). The trauma survivor Winnie Wen engages in diverse behaviors to fight and resist her prolonged traumas. She refuses to submit and develops resisting

${ }^{3}$ Pearl suffers from multiple sclerosis. 
techniques both visible and invisible. Ultimately, the survivor's testimonies bear witness to their resilience and survival strategies that enabled them to recover.

\section{BIBLIOGRAPHY}

[1]. Adams, Bella. Amy Tan: Contemporary World Writers .U.K: Manchester Press. 2005

[2]. Caruth, Cathy.Trauma Explorations in Memory. Baltimore. The John Hopkins University Press, 1995.

[3]. Chang, Iris. The Rape of Nanking: The Forgotten Holocaust of World War Two. New York: Penguin books.1997

[4]. Chesler, Phyllis. Women and Madness. New York: Four Walls Eight Windows, 1997.

[5]. Cheung,King-Kog.An Interethnic Companion to Asian American Literature. Cambridge: University Press, 1997.

[6]. Farrell, Kirby. Post-Traumatic Culture: Injury and Interpretation in the Nineties. Baltimore. The John Hopkins University Press, 1998.

[7]. Felman, Shoshana. "The Vicissitudes of Teaching".Crises of Witnessing in Literature, Psychoanalysis, and History. New York: Routelge, 1992.

[8]. Herman, Judith Lewis. Trauma and Recovery. The United States of America: Basic Books, 1992

[9]. Huntley, E.D. Amy Tan a Critical Companion .U.S.A: Greenwood Press, 1998.

[10]. LaCapra, Dominick: Writing History, Writing Trauma. Baltimore. Johns Hopkins University Press, 2001.

[11]. Laub, Dori "Bearing Witness, or the Vicissitudes of Listening". Crises of Witnessing in Literature, Psychoanalysis, and History. New York: Routelge, 57-74, 1992.

[12]. Luckhurst, Roger. The Trauma Question. London: Routledge, 2008.

[13]. Shay, Jonathan. Achilles in Vietnam: Combat Trauma and the Undoing of Character. New York: Scribner, 1997.

[14]. Tan, Amy. The Kitchen God's Wife. New York: Ballantine Books, 1991.

[15]. ---,The Opposite of Fate.Memoir of a writing Life. U.S.A.: Penguin Books, 2003.

[16]. White, Hayden. Tropics of Discourse Essays in Cultural Criticism. Baltimore: The John Hopkins university Press, 1978. 